\title{
The Influence of Gaseous Pollutants on Silver Artifacts Tarnishing
}

\author{
Yussri Salem \\ Conservation Department, Faculty of Archaeology, South Valley University, Qena, Egypt \\ Email: yousry.ali@arch.svu.edu.eg
}

How to cite this paper: Salem, Y. (2017) The Influence of Gaseous Pollutants on Silver Artifacts Tarnishing. Open Journal of Air Pollution, 6, 135-148.

https://doi.org/10.4236/ojap.2017.64011

Received: September 20, 2017

Accepted: November 21, 2017

Published: November 24, 2017

Copyright $\odot 2017$ by author and Scientific Research Publishing Inc. This work is licensed under the Creative Commons Attribution International License (CC BY 4.0).

http://creativecommons.org/licenses/by/4.0/

c) (i) Open Access

\begin{abstract}
The present work investigated the effect of the common gaseous pollutants on silver artifacts corrosion. The study will be carried out on manufactured coupons of silver alloy (91 silver, 9 copper) which have chemical composition similar to ancient Egyptian silver artifacts. These coupons will be exposed to gaseous pollutants of each individual gas; such as Sulfur dioxide, Nitrogen dioxide, Carbon dioxide, Hydrogen sulfide and Chlorine. The exposure period will be four weeks in a climate chamber with gas concentration 10 PPM. After the test Examinations by SEM and PM were used to evaluate the effect of each gas and description the morphology of the corrosion layers. The results revealed that all gases reacted with the surface except carbon dioxide. The formed tarnishing layers varied in coverage and density rate. Corrosion products are analyzed by XRD and the results revealed $\mathrm{Ag}_{2} \mathrm{~S}, \mathrm{AgCl}, \mathrm{Ag}_{2} \mathrm{SO}_{4}$ and $\mathrm{Ag}_{2} \mathrm{O}$ as corrosion products.
\end{abstract}

\section{Keywords}

Silver, Artifacts, Atmospheric Corrosion, Gaseous Pollutants

\section{Introduction}

Archaeological silver and its alloys have relatively high resistance to corrosion products in the atmospheric environment compared to copper and iron objects. But in the presence of humidity and gaseous pollutants-special Sulphur containing pollutants-Silver is susceptible to the tarnishing and corrosion products will be formed. Many corrosion products such as $\mathrm{Ag}_{2} \mathrm{~S}, \mathrm{Ag}_{2} \mathrm{SO}_{4}, \mathrm{AgCl}$, have been identified on silver objects either in museum environment (displayed in cabinets and stored in depositories) or excavated from the burial environment. Silver objects corrosion in the atmospheric environmental attributed to the water layers on the surface which provide the reaction of the gaseous pollutants such as chloride anions, sulphates, carbonates 
and Sulphides with metallic surface and lead to the metal dissolution [1].

Among the family of ancient metals, the fewest studies on the laboratory and field exposure of the gaseous pollutants were presented to silver. Previous lab exposure tests often focused on silver tarnish due to Sulphur containing pollutants [2]-[7]. These studies have been agreed in their results which can be summarized in the formation of silver tarnish as black layer consisting of $\mathrm{Ag}_{2} \mathrm{~S}$ as major corrosion product and $\mathrm{Ag}_{2} \mathrm{SO}_{4}$ in a negligible quantity. Few lab exposure studies have been presented to impact other gaseous pollutants such as $\mathrm{Cl}, \mathrm{NO}_{2}$, and $\mathrm{CO}_{2}$, but the results were different and varied. The differences were as follow.

Results of Previous studies indicated that nitrogen dioxide is not considered a corrosion factor of silver because silver does not react with it, but it only acts as an accelerated factor of silver tarnish with other gases [8] [9] [10] [11] [12] even though Previous study found silver nitrate $\mathrm{Ag}_{2} \mathrm{NO}_{3}$ as corrosion products on exposed silver to $1.2 \mathrm{ppm} \mathrm{NO}_{2}$ for 40 hours [2].

Also $\mathrm{Ag}_{2} \mathrm{SO}_{4}$ as corrosion product was observed on silver coupons in field exposure [13] although the studies indicated that Silver sulfate $\left(\mathrm{Ag}_{2} \mathrm{SO}_{4}\right)$ forms only in artificially high levels of sulfur dioxide [14] [15].

Silver is sensitive to chloride $\left(\mathrm{Cl}^{-}\right)$and silver chloride will be formed as a result of the reaction [10] [11] [12] [15] [16] [17]. Also this does not agree with results revealed that silver chloride compound was not identified on surface film of silver coupons after the exposure in an ASTM B117 salt spray chamber [18] and this compatibility with previous studies mentioned that silver does not react directly with chlorine gas and the presence of silver chloride as corrosion product due to burial in a chloride rich environment [19] [20].

The laboratory-exposure studies of the effect of $\mathrm{CO}_{2}$ gas on silver are very few, although $\mathrm{Ag}_{2} \mathrm{CO}_{3}$ is distinguished as corrosion product of silver as result of the reaction with $\mathrm{CO}_{2}$ and although $\mathrm{CO}_{2}$ is abundant in the ambient environment of silver artifacts. So very little is known about the formation mechanism of $\mathrm{Ag}_{2} \mathrm{CO}_{3}$ Such as it is expected only in strong alkaline solutions [21]. $\mathrm{Ag}_{2} \mathrm{CO}_{3}$ product corrosion has not been detected as corrosion product on the silver artifacts. Also $\mathrm{Ag}_{2} \mathrm{CO}_{3}$ was identified in a recent study of field-exposure study on the silver coupons exposed to various outdoor environments and the product was detected only in one site which distinguished above the temperature inversion layer [1].

Therefore, in this study, the effects of gases $\left(\mathrm{NO}_{2}, \mathrm{Cl}, \mathrm{CO}_{2}\right)$ on silver will be presented as a laboratory exposure and the results will be compared with previous studies. Also they did not take sufficient laboratory studies although they were common gaseous pollutants in outdoor and indoor atmospheric environment, also hydrogen sulfide and sulfur dioxide were chosen as main gases in silver tarnish and lead to silver sulfide which was often observed as corrosion product of silver.

\section{Experimental Procedures}

\subsection{Coupons Preparation}

Silver coupons should be similar for archaeological silver of ancient Egypt civili- 
zation, different concentrations were found in Ancient Egyptian Silver, elemental analysis of a number of Egyptian silver artefacts showed that the concentration of silver in 10 objects between 83 to $90 \%$, and between 90 to $95 \%$ of 19 other objects [22] [23]. Also analyses of Babylonian coins from silver copper alloy were about $87 \%-90 \%$ purity [21]. So that a composition of coupons was $\mathrm{Ag} 89.4 \%$ and $\mathrm{Cu}$ $10.5 \%$.This concentration was not artificial available and was manufactured by alloying a mixture of silver (pieces from the pure silver) with pure copper pieces. The coupons were made by direct addition of silver and copper in a crucible Figure 1 [24]. The dimensions were $(3 \mathrm{~cm} \times 5 \mathrm{~cm} \times 0.08 \mathrm{~cm})$ Figure 2. XRF analysis used to determine the Composition.

Thin thickness of coupons about $8 \mathrm{~m}$ will be suitable and similar to silver artifacts thickness. most the silver artefacts were manufactured to thin sheets such as thin sheets for royal garments, hollow statues, jewellery items, funeral items, Household items of everyday life such as, spoons, jugs, cups, vessels, pots, covered wooden object, bowls and Other usages. Successive processes of hammering and ductility with the annealing on alloy rod to obtain thin thickness about $0.8 \mathrm{~mm}$. Five new coupons were used for each gas test; a hole was drilled in each sample for suspension in the chamber middle [21].

\subsection{Design and Preparation of Climate Chamber Test}

Climate chamber was designed according to ASTM [25]. It is made of $1000 \mathrm{~cm}$

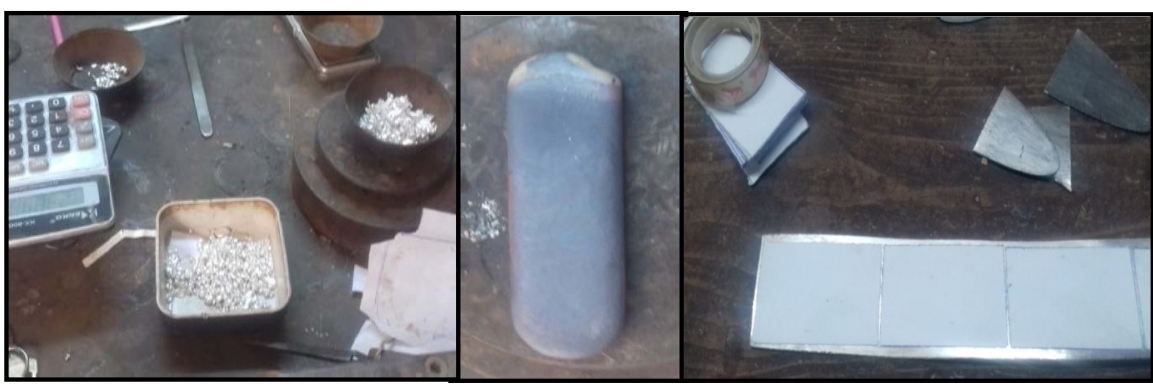

Figure 1. Manufacturing to silver coupons: (a) Pure silver pieces; (b) Shape of resulting rod after casting; (c) Cutting coupons after ductility and hammering processes.

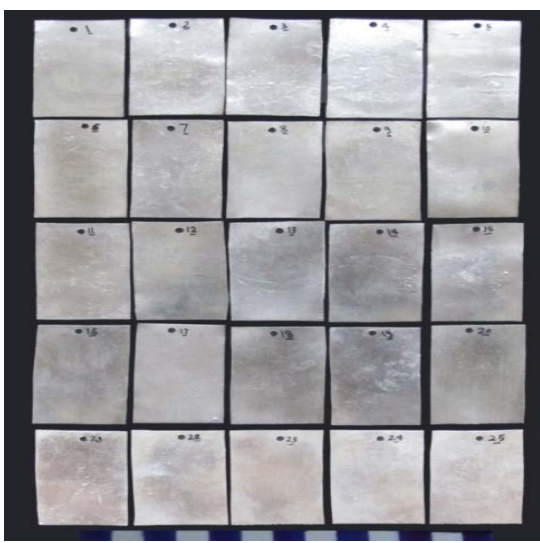

Figure 2. Silver alloy coupons before the exposure. 
diameter Perspex cylinder. The humidity was controlled gradually by the cup of saturated salt solution inside the chamber, the approximately $85 \% \mathrm{RH}$ was obtained by a saturated solution of potassium chloride [26] and the chamber was only opened to remove coupons. Heating of the air inside the chamber is done by a cartridge heater, the air inside the chamber is continuously mixed by a fan, which was suspended from the ceiling of the chamber, the temperature and relative humidity inside the chamber are continuously measured by a data logger device [27] [28]. A few studies were presented on the silver deterioration tests inside climate chamber, these studies used two types of the deterioration factors: high relative humidity [10] [29] and gaseous pollutants in presence relative humidity [2] [25] [29]. Most studies of silver deterioration were used corrosive solutions as deterioration factors, such as $\mathrm{BaS} 5 \mathrm{~g} / \mathrm{l}$ solution for 24 Hours [18] and $\mathrm{Na}_{2} \mathrm{~S}$ were used as the tarnishing solution [30] [31]. Acetic acid solutions were used as simulation of emissions vapors in wooden cabinets and $\mathrm{CuCl}_{2} 50 \mathrm{~g} / \mathrm{l}$ for $20 \mathrm{~min}$, and $\mathrm{NaCl}$ [29] were used of AgCl silver patina [19].

\subsection{The Test Gases}

The gases for the test were as follows: Sulfur dioxide $\mathrm{SO}_{2}$, Nitrogen dioxide $\mathrm{NO}_{2}$, Carbon dioxide $\mathrm{CO}_{2}$, Chlorine gas $\mathrm{Cl}$ and Hydrogen Sulphide $\mathrm{H}_{2} \mathrm{~S}$. The gas is mixed with the present air in inside chamber. Those types were the most influence in deterioration of silver artefacts.

\subsection{Test Procedures}

Each five coupons were exposed to humidified air containing concentration 10 ppm of one gas only. Accelerated conditions parameters were as shown in Table 1. The values of conditions parameters were chosen after survey of 29 previous studies which included lab exposure of ancient metals family (copper, bronze, silver, steel and lead) as shown in Table 2. Their most experiments were performed at room temperature $\left(22^{\circ} \mathrm{C}-25^{\circ} \mathrm{C}\right)$, and relative humidity between $80-90$. The other two factors such as the gases concentration and the exposure period differed from study to another.

Cylinders $99.9 \%$ concentration were used to obtain of $\mathrm{CO}_{2}, \mathrm{SO}_{2}$ and $\mathrm{NO}_{2}$ gases, The gas flowed from cylinder into the exposure chamber after the calculation of flow and time of the required concentration. $\mathrm{H}_{2} \mathrm{~S}$ and $\mathrm{Cl}^{-}$were prepared in lab, $\mathrm{H}_{2} \mathrm{~S}$ prepared by the reaction of hydrochloric acid diluted with ferrous sulfide (Equation (1)) [51] and $\mathrm{Cl}^{-}$prepared by the interaction of concentrated $\mathrm{Cl}^{-}$ with manganese dioxide (Equation (2)) [52]. According to the law of Avogadro and Lussac can be calculated Volume which the required concentration of $\mathrm{H}_{2} \mathrm{~S}$ and $\mathrm{Cl}^{-}$inside the chamber is occupied. Where Molecular weight (one mole) of any gas under standard conditions is occupied $22,400 \mathrm{ml}$ (The molar volume, Equation (3)) [53], and by the calculated of molecular weight to $\mathrm{H}_{2} \mathrm{~S}$ Equation (4) which occupied $22,400 \mathrm{ml}$ can be calculated volume of the required concentration of $\mathrm{H}_{2} \mathrm{~S}$ Equation (5). 


$$
\begin{gathered}
\mathrm{FeS}+2 \mathrm{HCl} \rightarrow \mathrm{FeCl}_{2}+\mathrm{H}_{2} \mathrm{~S} \\
4 \mathrm{HCl}+\mathrm{MnO}_{2} \rightarrow \mathrm{MnCl}_{2}+2 \mathrm{H}_{2} \mathrm{O}+\mathrm{Cl}_{2}
\end{gathered}
$$

1 mole of a gas at STP $=22.4$ liters of a gas

$$
2 \mathrm{X} 1+32=34 \mathrm{~g}=22400 \mathrm{ml}
$$

$$
10 \mathrm{ppm}\left(19 \mathrm{mg} / \mathrm{m}^{3}\right)=\mathrm{X}
$$

Gas syringe was used to get the required volume and injected it into inside chamber Figure 3, the fan was used for mixing gases and its distribution inside the chamber.

\begin{tabular}{|c|c|c|c|c|c|c|}
\hline Ref. & Gas & Time & Concentration & $\mathrm{C}$ & RH & Coupons \\
\hline [32] & $\mathrm{OCS}, \mathrm{H}_{2} \mathrm{~S}, \mathrm{SO}_{2}$ & 5 week & $\begin{array}{l}2.5-0.26 \mathrm{ppm} \\
2.66-3.64 \mathrm{ppm}\end{array}$ & 22 & 50 & Silver \\
\hline$[33]$ & $\mathrm{SO}_{2}, \mathrm{NO}_{2}$ & 30 hours & $10-22$ ppm, 1.8 ppm & 25 & $80 \%-90 \%$ & Tin \\
\hline$[34]$ & $\mathrm{H}_{2} \mathrm{~S}$ & 22 - 77 days & $50 \mathrm{ppb}, 2 \mathrm{ppm}$ & 30,80 & $40 \%$ & Copper \\
\hline$[36]$ & Acetic and formic acid vapors & $\begin{array}{l}\text { One, two and four } \\
\text { weeks }\end{array}$ & $\begin{array}{l}\text { formic acid } 160 \mathrm{ppb} \text {, acetic acid } 170 \\
\qquad \mathrm{ppb}, \mathrm{CO}_{2} 350 \mathrm{ppm}\end{array}$ & 22 & $95 \%$ & Lead \\
\hline$[37]$ & $\mathrm{H}_{2} \mathrm{~S}, \mathrm{NO}_{2}, \mathrm{Cl}_{2}$ & 4,10 days & $10,200,10 \mathrm{ppb}$ & 30 & $70 \%$ & Copper \\
\hline$[38]$ & Mixture of $\mathrm{NO}_{2}, \mathrm{SO}_{2}, \mathrm{O}_{3}$ & & $200 \mathrm{ppb} \mathrm{SO}, 200 \mathrm{ppb} \mathrm{O} . \mathrm{NO}_{2} \mathrm{ppb}$ & 25 & $80 \%$ & Copper \\
\hline$[40]$ & Mixture of $\mathrm{SO}_{2}, \mathrm{H}_{2} \mathrm{~S}$ & & $\mathrm{SO}_{2} 75, \mathrm{H}_{2} \mathrm{~S} 50(\mathrm{ppb})$ & 25 & $75 \%$ & Copper \\
\hline$[41]$ & Mixture of $\mathrm{SO}_{2}, \mathrm{NO}_{2}$ & $10,30,60$ hour & $\mathrm{SO}_{2} 75, \mathrm{NO}_{2} 120(\mathrm{ppb})$ & 25 & $75 \%$ & Copper \\
\hline$[42]$ & $\begin{array}{l}\text { Formaldehyde, acetic and } \\
\text { formic acid }\end{array}$ & 135 days & $0.04,0.4,4 \mathrm{ppmv}$ & 25 & $54 \%, 75 \%$ & Copper, lead \\
\hline$[43]$ & formic and acetic acid & 21 days & $100,200,300 \mathrm{ppm}$ & 30 & $100 \%$ & Copper \\
\hline$[44]$ & $\mathrm{HNO}_{3}$ & 2 weeks & $126(\mathrm{ppb})$ & 25 & $65 \%$ & Copper, \\
\hline$[45]$ & $\mathrm{NO}_{2}, \mathrm{NO}_{2}+\mathrm{SO}_{2}$ & 2 weeks & $800,800+800\left(\mu \mathrm{g} / \mathrm{m}^{-3}\right)$ & 30 & $90 \%$ & Zinc \\
\hline$[46]$ & $\mathrm{SO}_{2}$ & 4 week & $(10 \mathrm{ppm})$ & 25 & $90 \%$ & Copper \\
\hline$[47]$ & $\mathrm{SO}_{2}+\mathrm{O}_{3}$ & 4 week & $476 \mathrm{ppb}+500(\mathrm{ppb})$ & 30 & $70 \%$ & Copper \\
\hline$[49]$ & $\mathrm{H}_{2} \mathrm{~S}$ & 4 week & $50-200(\mathrm{ppb})$ & 25 & $80 \%$ & Copper \\
\hline$[50]$ & $\mathrm{SO}_{2}+\mathrm{NO}_{2}$ & $14,21,28$ days & 200 and $800\left(\mu \mathrm{g} \cdot \mathrm{m}^{-3}\right)$ & 35 & 70,90 & Copper \\
\hline [29] & $\mathrm{O}_{3}$ & $24 \mathrm{~h}$ & $500 \mathrm{ppb}$ & 25 & $50 \%, 90 \%$ & Silver \\
\hline
\end{tabular}

Table 1. Conditions and procedures of the test.

\begin{tabular}{cccc}
\hline Period & T & RH & Concentration \\
\hline $\mathbf{8}$ weeks & $25^{\circ} \mathrm{C}$ & $85 \%$ & $10 \mathrm{ppm}$ \\
\hline
\end{tabular}

Table 2. Summarizes lap exposure conditions to gaseous pollutants with ancient metals in the previous studies. 


\section{Results and Discussion}

\subsection{Examination of the Samples after the Test}

All the coupons surfaces interacted with the gases from the first week except the exposed coupons to carbon dioxide. The reaction behavior inside the chamber and the growth rate of the tarnishing layer were similar among $\mathrm{Cl}, \mathrm{H}_{2} \mathrm{~S}$, and $\mathrm{NO}_{2}$. The interaction began as a very thin layer on the surface and the growth of tarnishing was generally rapid then became slow. The surface appearance turned from light interference tones to a grey and, finally, black film. Also the tarnishing rate was increased with $\mathrm{H}_{2} \mathrm{~S}, \mathrm{Cl}$, decreased with $\mathrm{SO}_{2}, \mathrm{NO}_{2}$ as shown in Figure 4.

The Coupons were examined after each test by Visual examination, Polarizing Microscope and Scanning Electron Microscope to identify the morphology of the formed layer and evaluate the interaction between the coupons surface and the test gases. The investigation results revealed that the formed tarnishing layer, thickness, density and coverage of the surface were differed among the test coupons as shown in Figure 5. $\mathrm{H}_{2} \mathrm{~S}$ coupons recorded the highest thickness, density and coverage of the formed layer. Also $\mathrm{H}_{2} \mathrm{~S}$ caused pitting in the metallic core. $\mathrm{Cl}$ coupons were completely covered by a uniform general dense layer of silver tarnishing. $\mathrm{CO}_{2}$ coupons revealed very weak effect of gas. Slightly tarnishing layer with green spots were observed on the surface of $\mathrm{NO}_{2}$ coupons. $\mathrm{SO}_{2}$ coupons showed the least tarnishing layer and the reaction was very slow although humidity existed, the slow reaction of $\mathrm{SO}_{2}$ with silver was mention in previous studies [35].

\subsection{The Analysis of Corrosion Products by X-Ray Diffraction and Raman Spectroscopy}

The coupons were exposed to X-ray diffraction to analyze the formed patina.

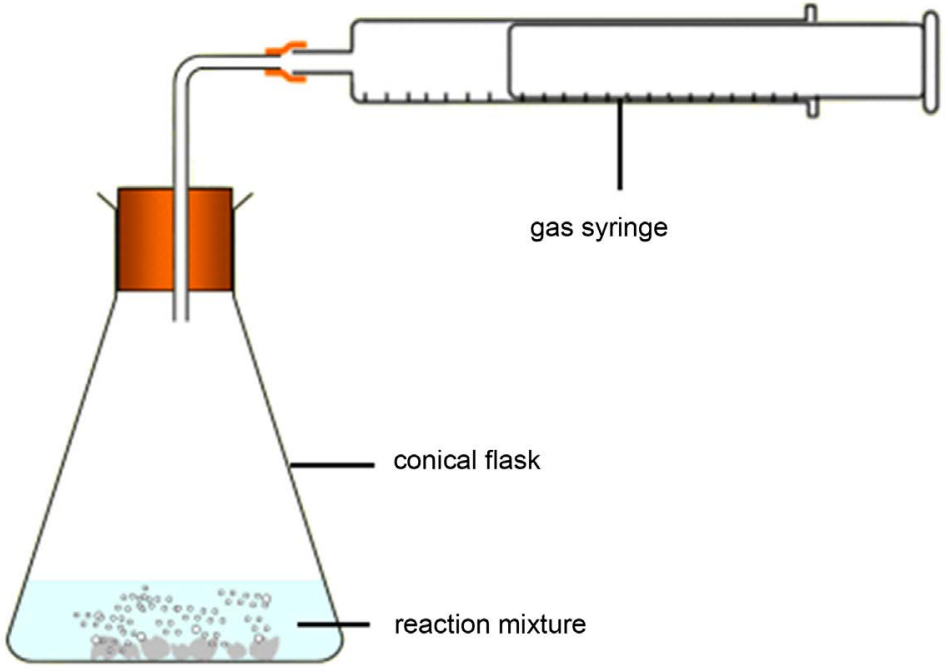

Figure 3. The syringe and the method of taking the required volume from the gas resulting from the interaction. 


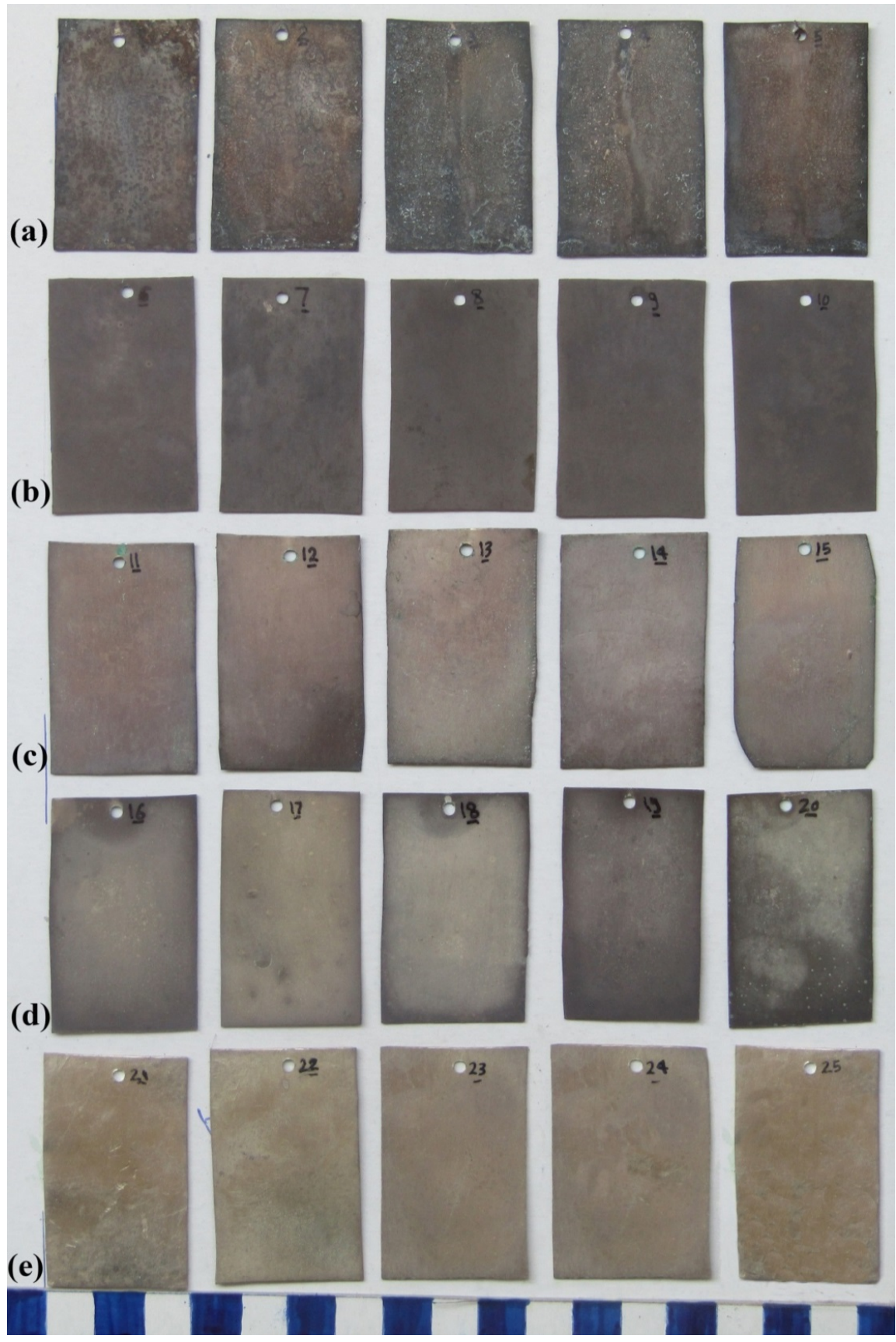

Figure 4. The coupons after the test: (a) The coupons exposed of $\mathrm{H}_{2} \mathrm{~S}$; (b) The coupons exposed of $\mathrm{Cl}$; (c) The coupons exposed of $\mathrm{SO}_{2}$; (d) The coupons exposed of $\mathrm{NO}_{2}$; (e) The coupons exposed of $\mathrm{CO}_{2}$.

This was showed many of corrosion products as in Figure 6 and Table 3.

The Raman spectrum of the tarnishing formed with $\mathrm{H}_{2} \mathrm{~S}$ shows four intensive bands in the range of $80-274 \mathrm{~cm}^{-1}$, Apart from the bands related to silver lattice vibrations at 93 and $147 \mathrm{~cm}^{-1}$, the others can be assigned to Ag-S-Ag symmetric stretching mode in particular at 93,188 and $243 \mathrm{~cm}^{-1}$ with a shoulder at $273 \mathrm{~cm}^{-1}$ [54]. The Raman spectrum confirmed XRD result because the bands revealed acanthite product Figure 7(a). 


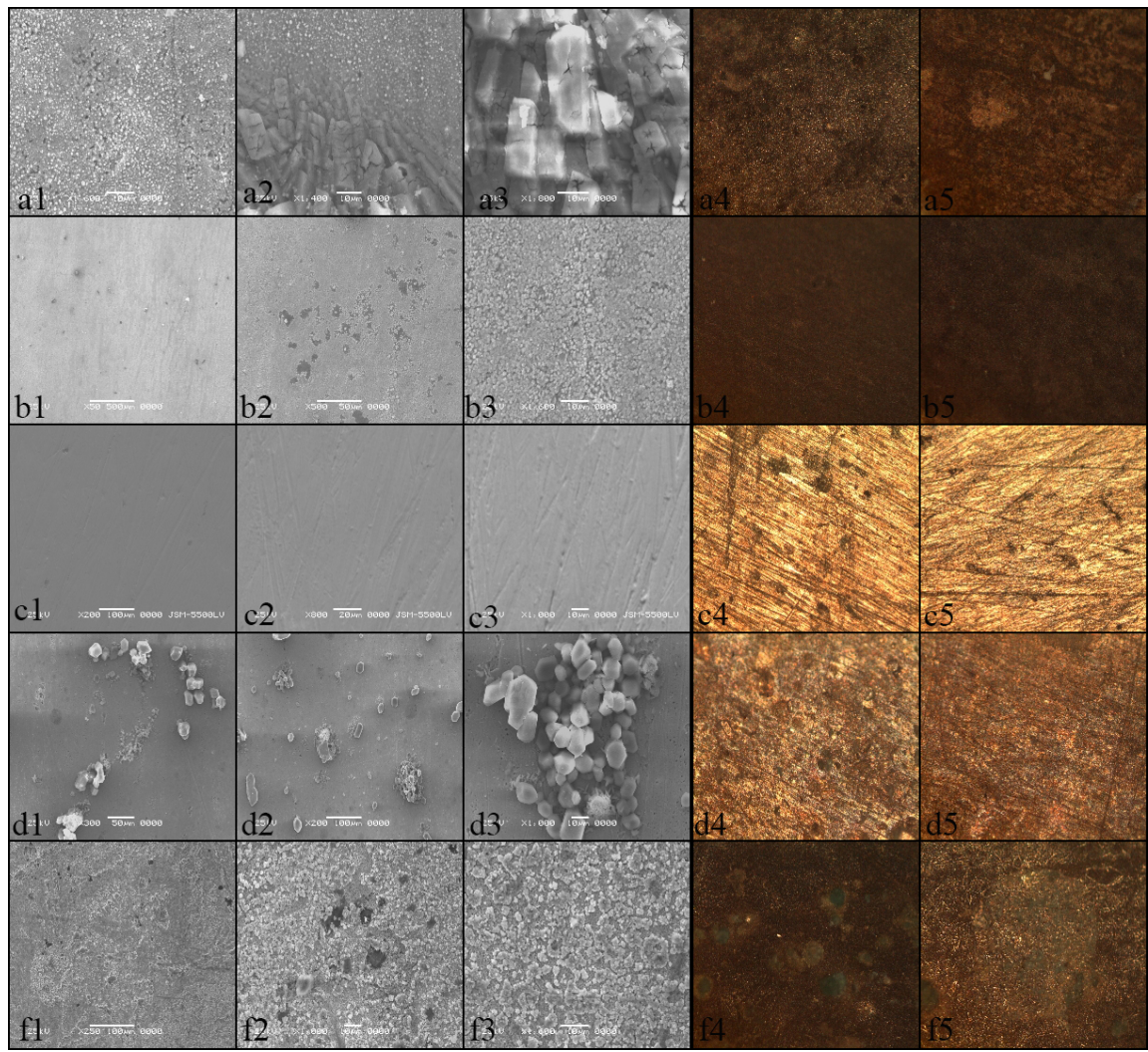

Figure 5 . Investigation by SEM and polarizing microscope $\times 500$ show the most important characteristics of tarnishing layer on the surface such as $\mathrm{H}_{2} \mathrm{~S}$ coupons are covered by dense tarnishing layer (a1)-(a5); $\mathrm{Cl}$ coupons reveal a uniform and thick tarnishing layer (b1)-(b5); $\mathrm{CO}_{2}$ coupons reveal very weak effect of the gas (c1)-(c5); $\mathrm{SO}_{2}$ coupons reveal the crystal structure of product of tarnishing (d1)-(d5); Green spots on the surface of $\mathrm{NO}_{2}$ coupons (f1)-(f5).

Table 3. Corrosion products on the coupons after the test.

\begin{tabular}{ccccc}
\hline $\mathrm{SO} 2$ & $\mathrm{Cl}$ & $\mathrm{CO}_{2}$ & $\mathrm{H}_{2} \mathrm{~S}$ & $\mathrm{NO}_{2}$ \\
\hline & & & $\mathrm{Ag}$ & $\mathrm{Ag}$ \\
$\mathrm{Ag}$ & $\mathrm{AgCl}$ & $\mathrm{Ag}$ & $\mathrm{AgO}$ & $\mathrm{Ag}_{2} \mathrm{O}$ \\
$\mathrm{Ag}_{2} \mathrm{O}$ & $\mathrm{Ag} \mathrm{Ag}_{2} \mathrm{O}$ & $\mathrm{AgO}$ & $\mathrm{Ag}_{2} \mathrm{~S}$ & $\mathrm{Ag}_{\left(\mathrm{NO}_{3}\right)_{3}(\mathrm{NO})_{3}}$ \\
$\mathrm{Ag}_{2} \mathrm{SO}_{4}$ & $\mathrm{Ag}$ & & $\mathrm{Cu}_{2}\left(\mathrm{NO}_{3}\right)(\mathrm{OH})_{3}$ \\
& & & $\mathrm{Ag}_{2} \mathrm{CuS}_{2}$ & \\
\hline
\end{tabular}

The Raman spectrum of $\mathrm{Cl}$ gas coupon presented sharp and highly intensive band at $236 \mathrm{~cm}^{-1}$, two weak bands at 145 and $349 \mathrm{~cm}^{-1}$, these beaks agreement with the main beaks of $\mathrm{AgCl}$ bands as in reference [54] Figure 7(b), the layer tarnishing of other gases was so slight that it was not identified by Raman.

Silver sulfide ( $\mathrm{Ag}_{2} \mathrm{~S}$ Acanthite): they were identified as abundant on silver artifacts. The reaction behavior between gas $\mathrm{H}_{2} \mathrm{~S}$ and the silver surface to form these products explains Equations (6) and (7).

$$
\begin{gathered}
4 \mathrm{Ag}+\mathrm{O}_{2}+2 \mathrm{H}_{2} \mathrm{~S} \rightarrow 2 \mathrm{Ag}_{2} \mathrm{~S}+2 \mathrm{H}_{2} \mathrm{O} \\
2 \mathrm{Ag}+\mathrm{H}_{2} \mathrm{~S} \rightarrow \mathrm{Ag}_{2} \mathrm{~S}+\mathrm{H}_{2}
\end{gathered}
$$



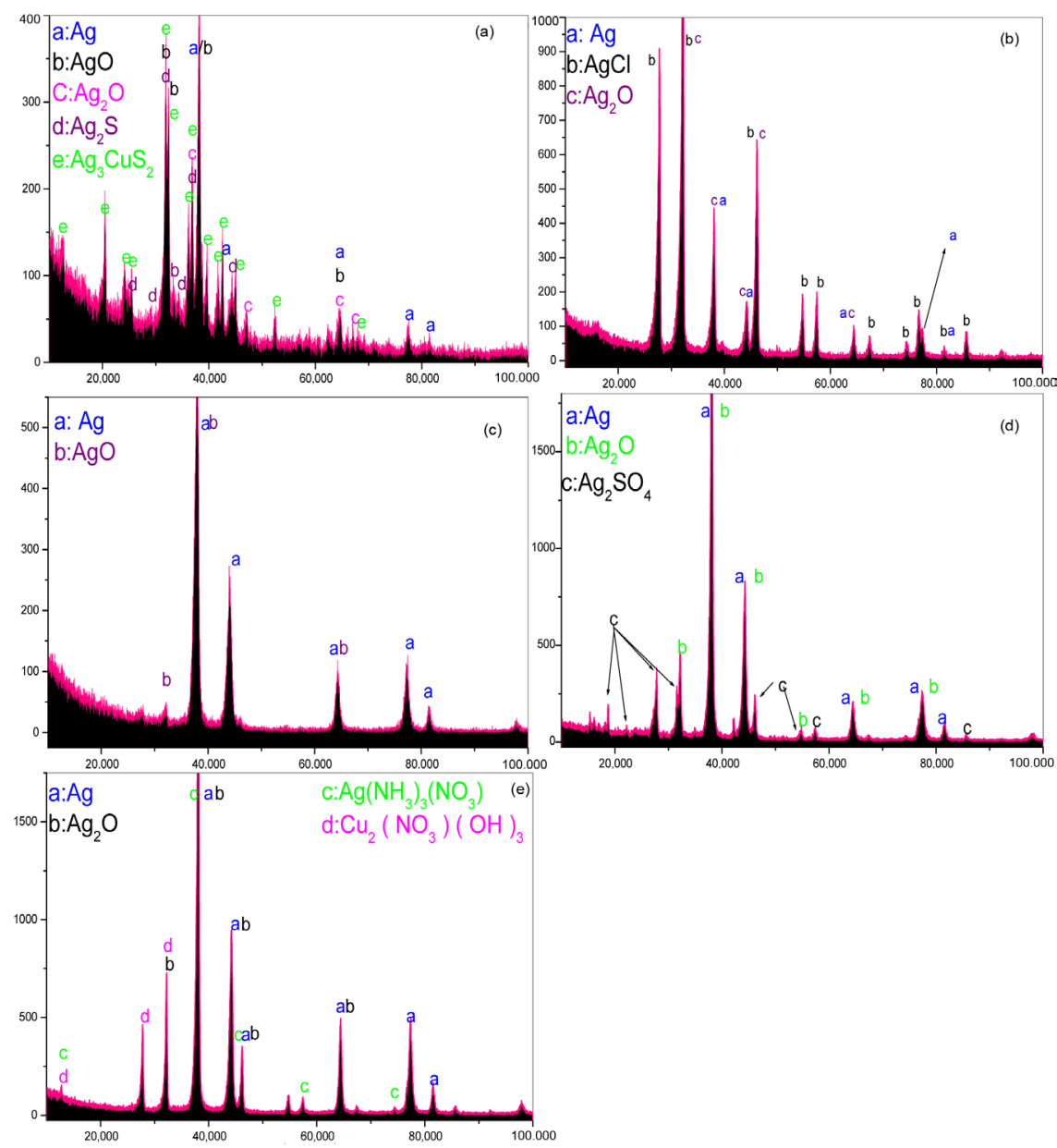

Figure 6. XRD patterns of tarnishing layers of the coupons: (a) Tarnishing of $\mathrm{H}_{2} \mathrm{~S}$; (b) Tarnishing of $\mathrm{Cl}$; (c) The coupons of $\mathrm{CO}_{2}$; (d) Tarnishing of $\mathrm{SO}_{2}$; (e) Tarnishing of $\mathrm{NO}_{2}$.

Silver chloride ( $\mathrm{AgCl}$ Cerargyrite, chlorargyrite): In this case, the dominant theory in the interpretation of formation mechanism of chloroargyrite $\mathrm{AgCl}$ is the transformation of $\mathrm{Ag}_{2} \mathrm{O}$ to $\mathrm{AgCl}$ as Equation (8) [13] [14]

$$
\mathrm{Ag}_{2} \mathrm{O}+2 \mathrm{Cl}^{-}+\mathrm{H}_{2} \mathrm{O} \rightarrow 2 \mathrm{AgCl}+2 \mathrm{OH}^{-}
$$

Silver sulfite $\left(\mathrm{Ag}_{2} \mathrm{SO}_{4}\right)$ : This product was identified in a previous study as corrosion product of silver [1] and the Equations (9)-(12) were suggested for the mechanism of its formation on silver coupons surface.

$$
\begin{aligned}
2 \mathrm{Ag}^{+}+2 \mathrm{OH}^{-} & \rightarrow \mathrm{Ag}_{2} \mathrm{O}+\mathrm{H}_{2} \mathrm{O} \\
\mathrm{OH}^{-}+\mathrm{SO}_{2} & \rightarrow \mathrm{HSO}_{3}^{-} \\
\mathrm{Ag}_{2} \mathrm{O}+\mathrm{HSO}_{3}^{-} & \rightarrow \mathrm{Ag}_{2} \mathrm{SO}_{3}+\mathrm{OH}^{-} \\
\mathrm{Ag}_{2} \mathrm{SO}_{3} & \rightarrow \mathrm{Ag}_{2} \mathrm{SO}_{4}
\end{aligned}
$$

Silver oxide $\mathrm{Ag}_{2} \mathrm{O}$ : Silver artifacts react with oxygen either by the electrochemical reactions in the presence of humidity (Equations (13)-(15)) or by chemical reactions in the absence humidity (Equation (16)). Therefore $\mathrm{Ag}_{2} \mathrm{O}$ and $\mathrm{AgO}$ are formed 


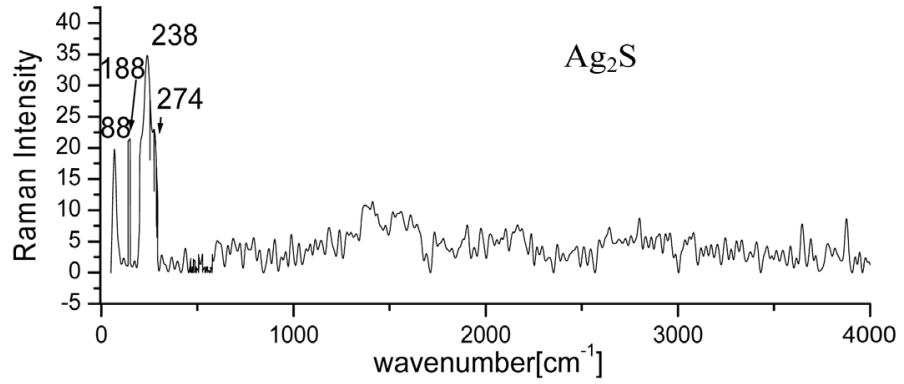

(a)

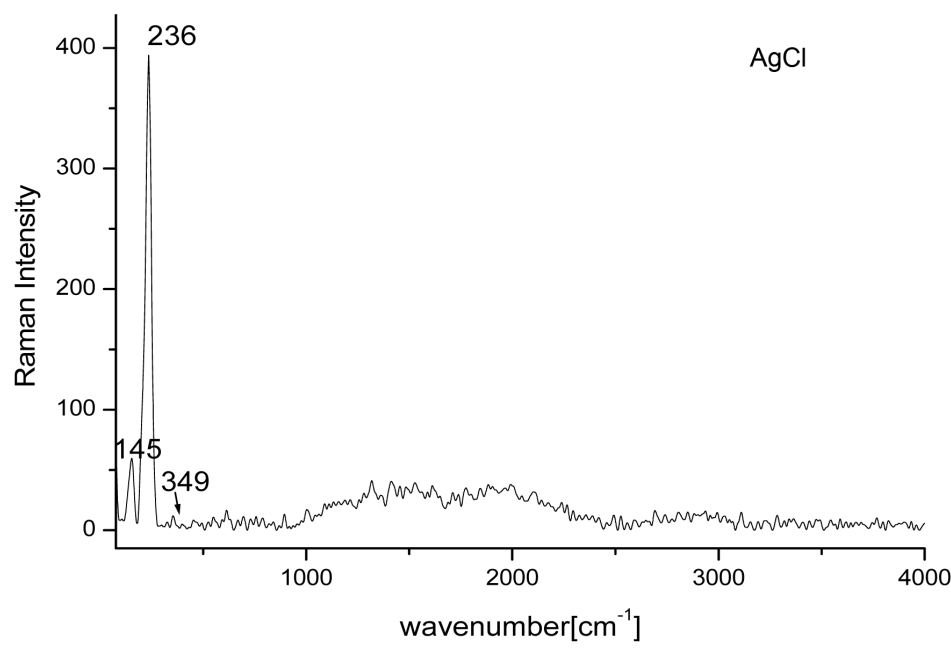

(b)

Figure 7. Raman spectrum of tarnishing of $\mathrm{H}_{2} \mathrm{~S}$ (a); tarnishing of $\mathrm{Cl}(\mathrm{b})$.

on silver artifacts surfaces.

$$
\begin{gathered}
\mathrm{Ag} \rightarrow \mathrm{Ag}^{+}+\mathrm{e}^{-} \\
\frac{1}{2} \mathrm{O}_{2}+\mathrm{H}_{2} \mathrm{O}+\mathrm{e}^{-} \rightarrow 2 \mathrm{OH}^{-} \\
2 \mathrm{Ag}^{+}+2 \mathrm{OH}^{-} \rightarrow \mathrm{Ag}_{2} \mathrm{O}+\mathrm{H}_{2} \mathrm{O} \\
\mathrm{Ag}+\frac{1}{2} \mathrm{O}_{2} \rightarrow \mathrm{Ag}_{2} \mathrm{O}
\end{gathered}
$$

Silver ammine nitrate $\left(\mathrm{Ag}\left(\mathrm{NO}_{3}\right)_{3}(\mathrm{NO})_{3}\right)$ : previous studies of filed and lab. exposure were identified only one product $\left(\mathrm{AgNO}_{3}\right)$ from nitrates anions as corrosion products on silver surface, Therefore this compound was expected of $\mathrm{NO}_{2}$ gas, but analysis showed Silver ammine nitrate $\left(\mathrm{Ag}\left(\mathrm{NO}_{3}\right)_{3}(\mathrm{NO})_{3}\right)$.

Copper Nitrate Hydroxide (Rouaite, $\mathrm{Cu}_{2}\left(\mathrm{NO}_{3}\right)(\mathrm{OH})_{3}$ ): Silver and copper are the coupons alloy elements, the formation of Rouaite corrosion product is contributed to selective corrosion of copper by the interaction of $\mathrm{cu}$ (as the main alloying element) with $\mathrm{NO}_{2}$ gas.

\section{Conclusions}

Silver in the ambient atmosphere and presence humidity is susceptible to the reac- 
tion with air pollutants. The tarnishing is formed not only in the presence of Sulphur containing pollutants but also there are other gaseous such as $\mathrm{Cl}$ and $\mathrm{NO}_{2}$.

Except the coupons of $\mathrm{CO}_{2}$, all the test coupons were exposed to tarnishing layer which was formed on the surface as a blackish thin film caused by the reaction of the metal surface with test pollutants. But highest layer in density and tarnishing was to $\mathrm{H}_{2} \mathrm{~S}$ gas.

\section{Found}

This research was founded by south valley university (Egypt).

\section{Acknowledgements}

I would like to thank Dr. Mai Rifai Con. Dep. Arch. Fac. Cai. Uni, for all assistance and support, Thanks also need to go to Dr. Adel Abdelkader Chem. Dep. Sci. Fac. Sou. Val. Uni. and prof. A.A. Shakour, Air Pollution Department, National Research Center, Egypt, for their helpful to adjust the gases concentration inside the chamber test.

\section{References}

[1] Sanders, C.E., Verreault, D., Frankel, G.S. and Allen, H.C. (2015) The Role of Sulfur in the Atmospheric Corrosion of Silver. Journal of the Electrochemical Society, 162, 630-637. https://doi.org/10.1149/2.0051512jes

[2] Kim, H. (2003) Corrosion Process of Silver in Environments Containing 0.1 ppm $\mathrm{H}_{2} \mathrm{~S}$ and $1.2 \mathrm{ppm} \mathrm{NO}_{2}$. Materials and Corrosion, 54, 243-250. https://doi.org/10.1002/maco.200390053

[3] Kleber, C., Wiesinger, R., Schnller, J., Hilfrich, U., Hutter, H. and Schreiner, M. (2008) Initial Oxidation of Silver Surfaces by S2- and S4-Species. Corrosion Science, 50, 1112-1121. https://doi.org/10.1016/j.corsci.2007.12.001

[4] Pope, D., Gibbens, H.R. and Moss, R.L. (1986) The Tarnishing of Silver at Naturally Occurring H2S and SO2 Levels. Corrosion Science, 8, 883-887. https://doi.org/10.1016/S0010-938X(68)80141-6

[5] Graedel, T.E., Franey, J.P., Gualtieri, G.J., Kammlott, G.W. and Malm, D.L. (1985) On the Mechanism of Silver and Copper Sulfidation by Atmospheric $\mathrm{H}_{2} \mathrm{~S}$ and OCS. Corrosion Science, 25, 1163-1180. https://doi.org/10.1016/0010-938X(85)90060-5

[6] Derdall, G. and Hyne, J.B. (1979) The Production of $\mathrm{H}_{2} \mathrm{~S}$ by Hydrolysis of Entrained COS in Hydrocarbon Liquids. Canadian Journal of Chemical Engineering, 57, 112-114. https://doi.org/10.1002/cjce.5450570119

[7] Lin, H. and Frankel, G.S. (2013) Accelerated Atmospheric Corrosion Testing of Ag. Corros., 69, 1060-1072. https://doi.org/10.5006/0926

[8] Guinement, J. and Fiaud, C. (1986) Laboratory Study of the Reaction of Silver and Copper with Some Atmospheric Pollutants. Proceedings of the 13 th ICEC Conference, Pattaya, 28-29 December 2017, 383-390.

[9] Abbott, W.H. (1987) The Development and Performance Characteristics of Mixed Flowing Gas Test Environments. IEEE Transactions on Components, Hybrids, and Manufacturing Technology, 11, 22-35.

[10] Graedel, T.E. (1992) Corrosion Mechanisms for Silver Exposed to the Atmosphere. Journal of the Electrochemical Society, 139, 1963-1970. https://doi.org/10.1149/1.2221162 
[11] Abbott, W.H. (1974) Effects of Industrial Air Pollutants on Electrical Contact Materials. IEEE Transactions on Parts, Hybrids, and Packaging, 10, 24-27. https://doi.org/10.1109/TPHP.1974.1134830

[12] Myers, M. (2009) Overview of the Use of Silver in Connector Applications. Technical Paper, Interconnection \& Process Technology Tyco Electronics, Harrisburg, PA, 503-516.

[13] Wan, Y., Wang, X., Wang, X., Li, Y., Sun, H. and Zhang, K. (2015) Determination and Generation of the Corrosion Compounds on Silver Exposed to the Atmospheres. International Journal of Electrochemical Science, 10, 2336-2354.

[14] Abbott, W.H. (1968) The Influence of Environment on Tarnishing Reactions. Proceedings of the 4 th ICEC Conference, Paris, 1968, 35-39.

[15] Rice, D., Peterson, P., Rigby, E., Phipps, P., Cappell, R. and Tremoureaux, R. (1981) Atmospheric Corrosion of Copper and Silver. Journal of the Electrochemical Society, 128, 275-284. https://doi.org/10.1149/1.2127403

[16] Liang, D., Allen, H.C., Frankel, G.S., Chen, Z.Y., Kelly, R.G., Wu, Y. and Wyslouzil, B.E. (2010) Effects of Sodium Chloride Particles, Ozone, UV, and Relative Humidity on Atmospheric Corrosion of Silver. Journal of the Electrochemical Society, 157, 146-156. https://doi.org/10.1149/1.3310812

[17] Ingo, G.M., Angelini, E., Riccucci, C., de Caro, T., Mezzi, A., Faraldi, F., Caschera, D., Giuliani, C. and Di Carlo, G. (2015) Indoor Environmental Corrosion of Ag-Based Alloys in the Egyptian Museum (Cairo, Egypt). Applied Surface Science, 326, 222-235. https://doi.org/10.1016/j.apsusc.2014.11.135

[18] Wan, Y., Macha, E.N. and Kelly, R.G. (2012) Modification of ASTM B117 Salt Spray Corrosion Test and Its Correlation to Field Measurements of Silver Corrosion. Corrosion, 68. https://doi.org/10.5006/1.3693699

[19] Novakovic, J., Georgiza, E. and Vassiliou, P. (2013) Nano-Alumina Modified Acrylic Coatings for Silver Protection. School of Chemical Engineering, NTUA, Athens, 23-25.

[20] Al-Saad, Z. and Bani Hani, M. (2007) Corrosion Behavior and Preservation of Islamic Silver Alloy Coins.

[21] Vassilio, P. and Gouda, V. (2013) Ancient Silver Artefacts: Corrosion Processes and Preservation Strategies. Corrosion and Conservation of Cultural Heritage Metallic Artefacts. In: European Federation of Corrosion (EFC) Series, Woodhead Publishing Limited and CRC Press, Oxford, 213-235. https://doi.org/10.1533/9781782421573.3.213

[22] Gale, N.H. and Stos-Gale, Z.A. (1981) Ancient Egyptian Silver. The Journal of Egyptian Archaeology, 67, 103-115. https://doi.org/10.2307/3856605

[23] Lucas, A. (2011) Ancient Egyptian Materials and Industries. 4th Edition, Dover Publications, London.

[24] Abu-Baker, A.N., MacLeod, I.D., Sloggett, R. and Taylor, R. (2013) A Comparative Study of Salicylaldoxime, Cysteine and Benzotriazole as Inhibitors for the Active Chloride-Based Corrosion of Copper and Bronze Artifacts. European Scientific Journal, 9, 1857-7881.

[25] ASTM D5116 (1997) Standard Guide for Small-Scale Environmental Chamber Determinations of Organic Emissions from Indoor Materials/Products.

[26] Young, J.F. (1967) Humidity Control in the Laboratory Using Salt Solutions-A Review. Journal of Applied Chemistry, 17, 241-245.

https://doi.org/10.1002/jctb.5010170901 
[27] Kim, M.N., Yu, H.S. and Lee, S.E. (2003) A Small Chamber Test and Oddy Test on Medium Density Fiberboard Grade (E0, E1). Indoor Air Quality in Museums and Historic Properties University of East Anglia, Norwich.

[28] Kim, S., Kim, J.A., An, J.Y., Kim, H.J., Kim, S.D. and Park, J.C. (2007) TVOC and Formaldehyde Emission Behaviors from Flooring Materials Bonded with Environmental-Friendly MF/PVAc Hybrid Resins. Indoor Air, 17, 404-415. https://doi.org/10.1111/j.1600-0668.2007.00488.x

[29] Wiesinger, R., Martina, I., Kleber, C. and Schreiner, M. (2013) Influence of Relative Humidity and Ozone on Atmospheric Silver Corrosion. Corrosion Science, 77, 69-76. https://doi.org/10.1016/j.corsci.2013.07.028

[30] Bernard, M.C., Dauvergne, E., Evesque, M., Keddam, M. and Takenouti, H. (2005) Reduction of Silver Tarnishing and Protection against Subsequent Corrosion. Corrosion Science, 47, 663-679. https://doi.org/10.1016/j.corsci.2013.07.028

[31] Lin, H., Frankel, G.S. and Abbott, W.H. (2013) Analysis of Ag Corrosion Products. Journal of the Electrochemical Society, 160, 345-355. https://doi.org/10.1149/2.055308jes

[32] Franey, J.P., Kammlott, G.W. and Graedel, T.E. (1985) The Corrosion of Silver by Atmospheric Sulfurous Gases. Corrosion Science, 25, 133-143. https://doi.org/10.1016/0010-938X(85)90104-0

[33] Sasaki, T., Kanagawa, R., Ohtsuka, T. and Miura, K. (2003) Corrosion Products of tin in Humid Air Containing Sulfur Dioxide and Nitrogen Dioxide at Room Temperature. Corrosion Science, 45, 847-854. https://doi.org/10.1016/S0010-938X(02)00151-8

[34] Tran, T.T.M., Fiaud, C. and Sutter, E.M.M. (2005) Oxide and Sulphide Layers on Copper Exposed to $\mathrm{H}_{2} \mathrm{~S}$ Containing Moist Air. Corrosion Science, 47, 1724-1737. https://doi.org/10.1016/j.corsci.2004.08.019

[35] Seo, M., Ishikawa, Y., Kodaira, M., Sugimoto, A., Nakayama, S., Watanabe, M., Furuya, S., Minamitani, R., Miyata, Y., Nishikata, A. and Notoya, T. (2005) Cathodic Reduction of the Duplex Oxide Films Formed on Copper in Air with High Relative Humidity at 60 Co, Corrosion Science, 47, 2079-2090. https://doi.org/10.1016/j.corsci.2004.09.016

[36] Niklasson, A., Johansson, L.G. and Svensson, J.E. (2007) Atmospheric Corrosion of Lead, The Influence of Formic Acid and Acetic Acid Vapors. Journal of the Electrochemical Society, 154, 618-625. https://doi.org/10.1149/1.2775173

[37] Lenglet, M., Lopitaux, J., Leygraf, L., Odnevall, I., Carballeira, M., Noualhaguet, J.C., Guinement, J., Gautier, J. and Boissel, J. (1995) Analysis of Corrosion Products Formed on Copper in $\mathrm{Cl}_{2} / \mathrm{H}_{2} \mathrm{~S} / \mathrm{NO}_{2}$ Exposure. Journal of the Electrochemical Society, 142, 3690-3696. https://doi.org/10.1149/1.2775173

[38] Astrup, T., Wadsak, M., Leygraf, C. and Schreinerb, M. (2000) In Situ Studies of the Initial Atmospheric Corrosion of Copper Influence of Humidity, Sulfur Dioxide, Ozone and Nitrogen Dioxide. Journal of the Electrochemical Society, 147, 2543-2551. https://doi.org/10.1149/1.1393566

[39] Samie, F., Tidblad, J., Kucera, V. and Leygraf, C. (2005) Atmospheric Corrosion Effects of $\mathrm{HNO}_{3}$-Method Development and Results on Laboratory Exposed Copper. Atmospheric Environment, 39, 7362-7373. https://doi.org/10.1149/1.1393566

[40] Rickett, B.I. and Payer, J.H. (1995) Composition of Copper Tarnish Products Formed in Moist Air with Trace Levels of Pollutant Gas: Hydrogen Sulfide and Sulfur Dioxide/Hydrogen Sulfide. Journal of the Electrochemical Society, 142, 3723-3728. https://doi.org/10.1149/1.2048404 
[41] Rickett, B.I. and Payer, J.H. (1995) Composition of Copper Tarnish Products Formed in Moist Air with Trace Levels of Pollutant Gas: Sulfur Dioxide and Sulfur Dioxide/Nitrogen Dioxide. Journal of the Electrochemical Society, 142, 3713-3722. https://doi.org/10.1149/1.2048403

[42] Tétreault, J., Cano, E., Bommel, M., Scott, D., Dennis, M., Barthés, L., Minel, L. and Robbio, L. (2003) Corrosion of Copper and Lead by Formaldehyde, Formic and Acetic Acid Vapours. Studies in Conservation, 48, 237-250.

https://doi.org/10.1179/sic.2003.48.4.237

[43] López-Delgado, A., Cano, E., Bastidas, J. and López, F. (2001) A Comparative Study on Copper Corrosion Originated by Formic and Acetic Acid Vapours. Journal of Materials Science, 36, 5203-5211. https://doi.org/10.1023/A:1012497912875

[44] Samie, F., Tidblad, J., Kucera, V. and Leygraf, C. (2007) Atmospheric Corrosion Effects of $\mathrm{HNO}_{3}$-Comparison of Laboratory-Exposed Copper, Zinc and Carbon Steel, Atmospheric Environment, 41, 4888-4896. https://doi.org/10.1016/j.atmosenv.2007.02.007

[45] Castano, J.G., de la Fuente, D. and Morcillo, M. (2007) A Laboratory Study of the Effect of $\mathrm{NO}_{2}$ on the Atmospheric Corrosion of Zinc. Atmospheric Environment, 41, 8681-8696. https://doi.org/10.1016/j.atmosenv.2007.07.022

[46] Oesch, S. and Faller, M. (1997) Environmental Effects on Materials: The Effect of the Air Pollutants $\mathrm{SO}_{2}, \mathrm{NO}_{2}, \mathrm{NO}$ and $\mathrm{O}_{3}$ on the Corrosion of Copper, Zinc and Aluminium. A Short Literature Survey and Results of Laboratory Exposures. Corrosion Science 39, 1505-1530. https://doi.org/10.1016/S0010-938X(97)00047-4

[47] Strandberg, H. and Johansson, L.G. (1997) Role of $\mathrm{O}_{3}$ in the Atmospheric Corrosion of Copper in the Presence of $\mathrm{SO}_{2}$. Journal of the Electrochemical Society, 144, 2334-2342. https://doi.org/10.1149/1.1837814

[48] Eriksson, P. and Johansson, L.G. (1986) The Role of $\mathrm{NO}_{2}$ in the Atmospheric Corrosion of Different Metals. Proceeding of 10 th Scandinavian Corrosion Congress. Stockholm, 43.

[49] Campin, M.J. (2003) Microstructural Investigation of Copper Corrosion: Influence of Humidity, Ph.D. Dissertation, New Mexico State University, Las Cruces.

[50] Mariaca, L., de la Fuente, D., Feliu, S., Simancas, J., Gonzalez, J.A. and Morcillo, M. (2008) Interaction of Copper and $\mathrm{NO}_{2}$ : Effect of Joint Presence of $\mathrm{SO}_{2}$, Relative Humidity and Temperature. Journal of Physics and Chemistry of Solids, 69, 895-904. https://doi.org/10.1016/j.jpcs.2007.10.003

[51] Wikipedia (2017) Hydrogen Sulfide. https://en.wikipedia.org/wiki/Hydrogen_sulfide

[52] Wikipedia (2017) Chlorine. https://en.wikipedia.org/wiki/Chlorine\#cite_ref-Greenwood789_7-1

[53] Vonderbrink, S.A. (2006) Laboratory Experiments for Advanced Placement Chemistry. 2nd Edition, Flinn Scientific, Inc., Batavia, 87.

[54] Martina, I., Wiesinger, R., Simbürger, D.J. and Schreiner, M. (2012) Micro-Raman Characterization of Silver Corrosion Products: Instrumental Set Up and Reference Darabase. Preservation Science, 9, 1-8.

[55] Sharma, S.P. (1978) Atmospheric Corrosion of Silver, Copper, and Nickel-Environmental Test. Journal of the Electrochemical Society, 125, 2005-2011. https://doi.org/10.1016/j.jpcs.2007.10.003

[56] Volpe, L. and Peterson, P.J. (1989) The Atmospheric Sulfidation of Silver in a Tubular Corrosion Reactor. Corrosion Science, 29, 1179-1196. https://doi.org/10.1016/0010-938X(89)90065-6 